Henning, J., and Rubenson, A. (1970). Fournal of Pharmacy and Pharmecology, 22, 553.

Holmes, J. C., and Fowler, O. (1962). Circulation Research, 10, 68.

Holtz, P., Stock, K., and Westermann, E. (1964). Nature, 203, 656.

Louis, W. J. (1972). Medical fournal of Australia. In press.

Shepherd, D. M., and West, G. B. (1953). Fournal of Physiology, 120, 15.

Sjoerdsma, A. (1959). Pharmacological Reviews, 11, 374.

Sjoerdsma, A. (1968). In Clinical Pharmacology, p. 65, vol. 3, Oxford, Pergamon Press.
Tabei, R., Spector, S., Louis, W. J., and Sjoerdsma, A. (1969). European Fournal of Pharmacology, 7, 39.

Von Studnitz, W., Kaser, H., and Sjoerdsma, A. (1963). New England Fournal of Medicine, 269, 232.

Voorhess, M. L. (1966). Pediatric Clinics of North America, 13, 3.

Watanabe, A. M., Chase, T. N., and Gordon, P. V. (1970). Clinical Pharmacology and Therapeutics, 11, 740.

Weil-Malherbe, H. (1956). Lancet, 2, 282.

Wurtman, R. (1965). New England fournal of Medicine, 273, 746.

\title{
Familial Acute Myeloid Leukaemia with Acquired Pelger-Huett Anomaly and Aneuploidy of C Group
}

\author{
JUGINDER KAUR, \\ D. CATOVSKY, \\ H. VALDIMARSSON, \\ O. JENSSON, \\ A. S. D. SPIERS
}

British Medical fournal, 1972, 4, 327-331

\section{Summary}

All five members of one generation in an Icelandic family were affected by acute myeloid leukaemia or preleukaemia. Two sibs died of acute myeloid leukaemia and another of myelofibrosis associated with leukaemic changes. The other two sibs are alive; one of them (the propositus) has haematological features consistent with preleukaemia; both of them have evidence of an abnormal cytogenetic clone in the bone marrow with 47 chromosomes, an extra chromosome in the $\mathbf{C}$ group. The finding of the acquired Pelger-Huët anomaly in the neutrophils of the five affected sibs suggests that a specific genetic cell defect has been transmitted with autosomal dominant characteristics. The presence of immunological deficiencies : and an undue susceptibility to oncogenic viruses, as suggested by warts affecting three family members, may have played a part in the pathogenesis of the leukaemic process.

\section{Introduction}

Current concepts of the pathogenesis of leukaemia suggest the interaction of genetic, environmental, and immunological factors (Gibson et al., 1968; Zuelzer and Cox, 1969; Gunz, 1970 Galton and Spiers, 1971). The demonstration of genetic factors in human leukaemia relies on the study of familial clusters of the disease, as genetic manipulations are possible only in animal leukaemias. Many families have been described in which two or more cases of leukaemia have accurred in the same or successive generations (Videbaek, 1947; Hayhoe, 1960; Heath and Moloney, 1965; McPhedran et al., 1969; Snyder et al., 1970). In adults this has been adequately shown in chronic lymphocytic leukaemia (Fraumeni et al., 1969; Gunz and Veale, 1969) but it is rare in acute myeloid leukaemia (Snyder et al., 1970). We have studied an Icelandic family in which all five members of a sibship were affected, two with acute myeloid leukaemia, one with myelofibrosis and leukaemic changes, and two with preleukaemia as evidenced by an abnormal bone marrow clone.

\footnotetext{
M.R.C. Leukaemia Unit, Royal Postgraduate Medical School, London W.12

JUGINDER KAUR, M.D., Research Fellow

D. CATOVSKY, M.D., Assistant Lecturer in Haematology

A. S. D. SPIERS, PH.D., M.R.A.C.P., Consultant Physician

Department of Immunology, Royal Postgraduate Medical School, H. VALDIMARSSON, M.D., Lecturer

Blodbankinn, Reyjavik, Iceland

O. JENSSON, M.D., Director
}

Transmission of a genetic defect with autosomal dominant characteristics was suggested by the findings of the acquired form of Pelger-Huët anomaly in the neutrophils of all the siblings and by the demonstration of aneuploidy of the $\mathrm{C}$ group of chromosomes in the bone marrow of two sibs. In addition immunological deficiencies and an increased susceptibility to virus infection were present in this family. The family pedigree is shown in Fig. 1.

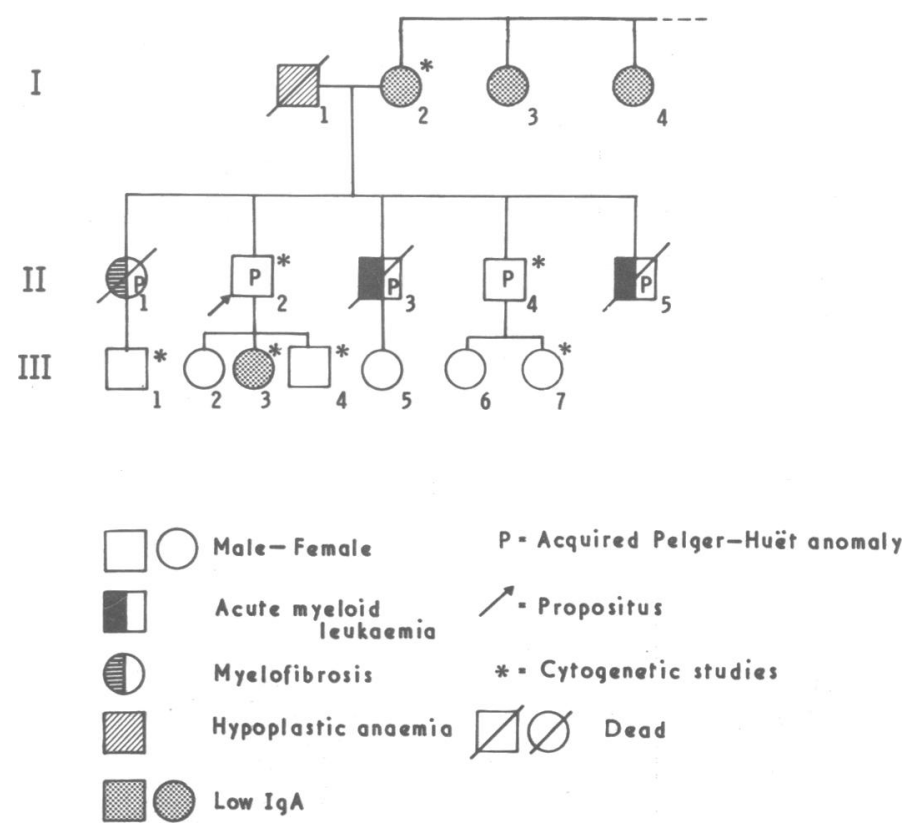

FIG. 1-Family pedigree.

\section{Case Reports}

Subject II 2.-This patient, the propositus, was referred to Hammersmith Hospical for investigation in March 1971 at the age of 37 . In 1959 he developed a chest infection affecting the left lower lobe. As the lesion did not resolve completely despite treatment a thoracotomy and decortication was performed five months later. Since that time he had suffered from chronic oral moniliasis. In 1966 he developed thrombophlebitis and in 1968 a perianal abscess. A necrotic granulomatous lesion developed subsequently which grew Candida albicans and led to the collapse of the bridge of his nose. In February 1969 he developed a right lower lobe pneumonia. The only physical signs at presentation were multiple warts affecting hands, feet, and neck, present for 15 years. The haemoglobin was $15.2 \mathrm{~g} / 100 \mathrm{ml}$, the P.C.V. $45 \%$, platelets were $81,000 / \mathrm{mm}^{3}$, and the W.B.C. was $7,800 / \mathrm{mm}^{3}$. Blood films showed a shift to the left with $1 \%$ of promyelocytes (Fig. $2 \mathrm{~A}$ ), $15 \%$ of myelocytes, and $52 \%$ of neutrophils. One-third of the neutrophils were found to have only two nuclear segments and some (including eosinophils) had a round nucleus (Pelger-Huet 
anomaly; Fig. 2 B). No monocytes were found. Bone marrow examination confirmed the pronounced shift to the left in the granulopoiesis and showed slight megaloblastic changes. Serum folate was reduced $(2.5 \mathrm{ng} / \mathrm{ml})$; serum vitamin $B_{12}$ and other biochemical tests were normal. The haematological abnormalities were regarded as consistent with a preleukaemic state. One year later he remained well and no further blood changes had occurred.

Subject II 1.-At the age of 15 (in 1948) this patient developed chronic elephantiasis of her left leg; this problem subsided after operations in 1950 but recurred in 1952 . In 1956 she started suffering from febrile episodes with pulmonary infiltrates. In 1958 she was found to be anaemic, with splenomegaly and pancytopenia. Blood films showed severe anisocytosis and poikilocytosis and $10 \%$ of blast cells, suggesting early leukaemic change. She died of pneumonia a year later. Necropsy showed myelofibrosis with myeloid metaplasia in the liver and spleen and chronic pneumonitis.

Subject II 3.-In 1959 at the age of 23 this man presented with cellulitis of the left arm and was found to be anaemic and leucopenic. He was treated with antibiotics and blood transfusions. A month later he was admitted with fever and multiple ecchymoses. The findings on bone marrow and peripheral blood examination were consistent with acute myeloid leukaemia of myeloblastic type (Fig. 2 C). He later developed an abscess in the left arm which required surgical drainage, after which he developed profuse bleeding. He died shortly afterwards.
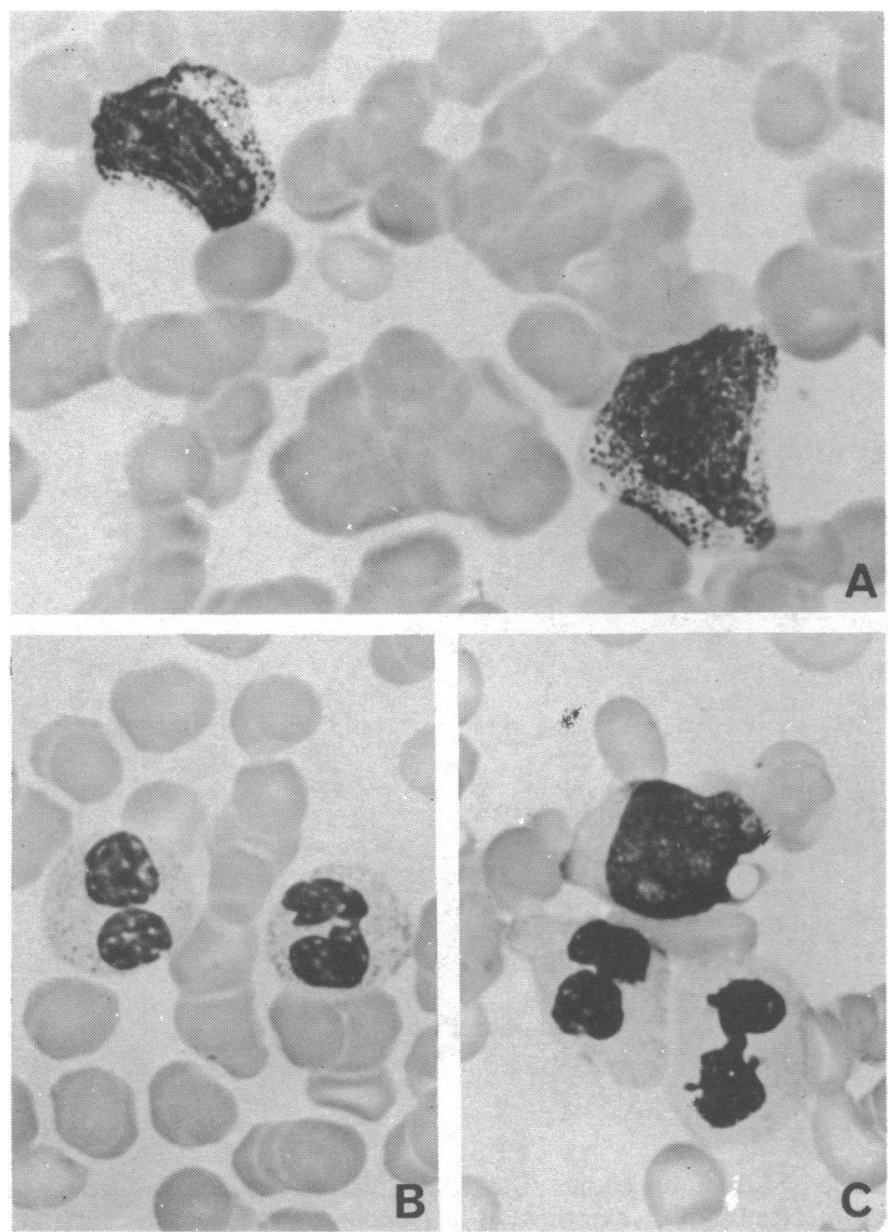

FIG. 2-Peripheral blood films ( $\times 1,600) \mathrm{A}$ and $\mathrm{B}$ from propositus (II 2) showing two promyelocytes (A) and two neutrophils with Pelger-Huët anomaly (B); C from case II 3 showing myeloblast and two Pelger neutrophils.

Subject II 5.-At the age of 16 (in 1966) this patient developed a perianal abscess. Because of the family history a blood count was performed and he was found to be leucopenic. He later developed leucocytosis with circulating myeloblasts. A diagnosis of acute myeloid leukaemia (myeloblastic-promyelocytic) was established after bone marrow examination. He died shortly afterwards of cerebral haemorrhage, and the necropsy findings were consistent with actute myeloid leukaemia.

Subject II 4.- This man aged 28 (in 1971) was in good health. The only past history of note was an operation for a perforated appendix and repeated perianal infections. Clinical examination showed nothing abnormal apart from multiple warts on the hands and feet, present for six years. At the time of writing he had a moderate degree of pancytopenia and a hypolastic bone marrow. Blood films showed the Pelger-Huett anomaly in a proportion of his neutrophils. Because of this and the chromosome findings (see below) he was thought to be in a preleukaemic state.

Subject I 1.-The father became ill at the age of 58 (in 1961). He gradually developed multiple infected skin ulcers. He was pancytopenic and required several blood transfusions. Döhle bodies were present in his neutrophils and the bone marrow showed hypoplasia. The skin ulcers became more widespread and his condition deteriorated. He died of pneumonia 17 months later.

Subject I 2.- The mother was alive and well at the age of 67 . She had, however, a single wart on one of her fingers. Blood and bone marrow examination showed nothing abnormal but low concentrations of serum IgA were found (see below).

\section{Summary of Clinical Findings}

(1) Haematological disorders were found in six members (Fig. 1) -hypoplastic anaemia (I 1), myelosclerosis with leukaemic changes (II 1), acute myeloid leukaemia (II 3 and II 5), and preleukaemia (II 2 and possibly II 4). Four of them had died within a relatively short period of time (1960-6), and the blood changes were discovered in subjects II $1,2,3$, and 5 between the ages of 16 and 25 years.

(2) Recurrent infections were associated with haematological changes in all members of the sibship.

(3) Two living sibs (II 2 and II 4) had generalized verrucosis, and the mother (I 2) had a single wart (Fig. 3). Histologically

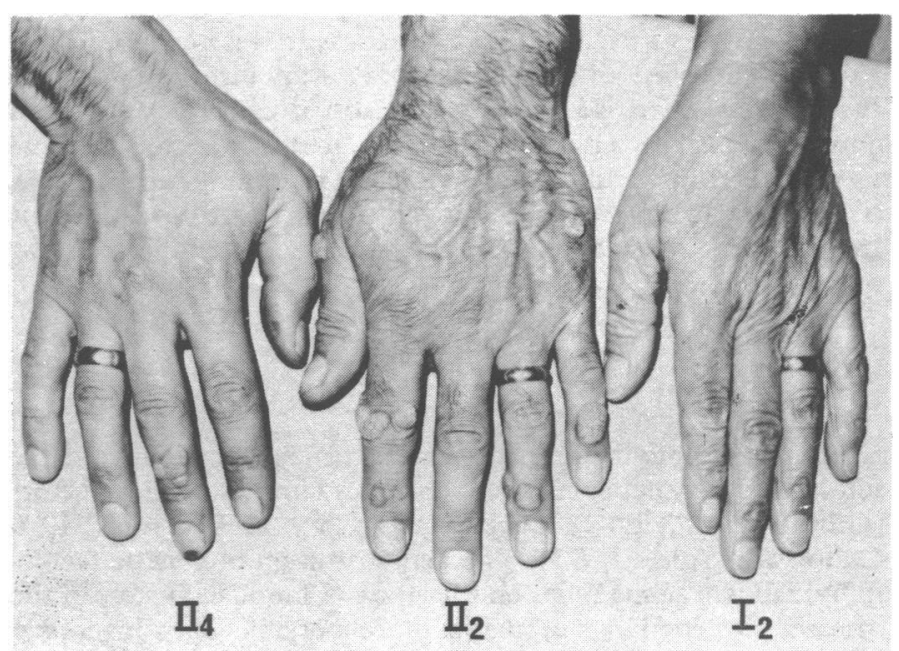

FIG. 3-Hands of members affected by warts.

the lesions were similar in each case and were consistent with the diagnosis of verruca vulgaris.

(4) The parents (I 1 and II 2) were not related, neither were the grandparents. There was no history of exposure to radiation or to chemicals. The family had lived in the same house in Reykjavik from 1932 to 1965.

\section{Laboratory Investigations}

\section{PELGER-HUËT NUCLEAR ANOMALY}

Blood films from all the members of generations I, II, and III (except I 1) were examined for the presence of this leucocyte abnormality. It was found in variable proportions of the neutrophils (Fig. 2 B, C) and eosinophils in all the members of generation II (Fig. 1). It was more prominent in the two living sibs (II 2 and II 4), affecting 30 to $40 \%$ of their neutrophils, predominantly in its bisegmented form (Sandoz, 1952). 
Retrospective study of the 1959 blood films from the propositus (II 2) showed the abnormality in 15 to $20 \%$ of his neutrophils. The anomaly was present, affecting 5 to $10 \%$ of the neutrophils, in the sibs who died of acute myeloid leukaemia or myelofibrosis. It was absent in blood films from member II 5 seven years before he developed acute myeloid leukaemia. The proportion of neutrophils affected, the absence of the anomaly in generation III, and the progressive characteristics in sibs II 2 and II 5 strongly suggest that the Pelger-Huët anomaly in this family corresponded to the acquired form of the abnormality (Sandoz, 1952; Shanbrom et al., 1960; Hayhoe et al., 1964; Wintrobe, 1968).

\section{LEUCOCYTE FUNCTION OF PROPOSITUS}

The following studies were carried out in the hope of elucidating the factors contributing to the frequent infections.

Neutrophil Function.-Phagocytosis and candidacidal activity (Lehrer and Cline, 1969) were moderately reduced; Pelger neutrophils phagocytosed as well as fully segmented neutrophils. The nitroblue-tetrazolium reduction test (Park et al., 1968) performed in the resting state and after in-vitro stimulation with Escherichia coli endotoxin gave a normal result; the activity in the neutrophil granules of alkaline phosphatase and myeloperoxidase was also normal.

Leucocyte Mobilization.-This was studied by means of Rebuck's skin window technique (Rebuck and Crowley, 1955). The initial response was both delayed and inadequate; by 12 hours there were moderate numbers of neutrophils (normal and Pelger) and hardly any mononuclear cells. The most striking feature in the later hours was the near absence of the mononuclear component (Fig. 4).

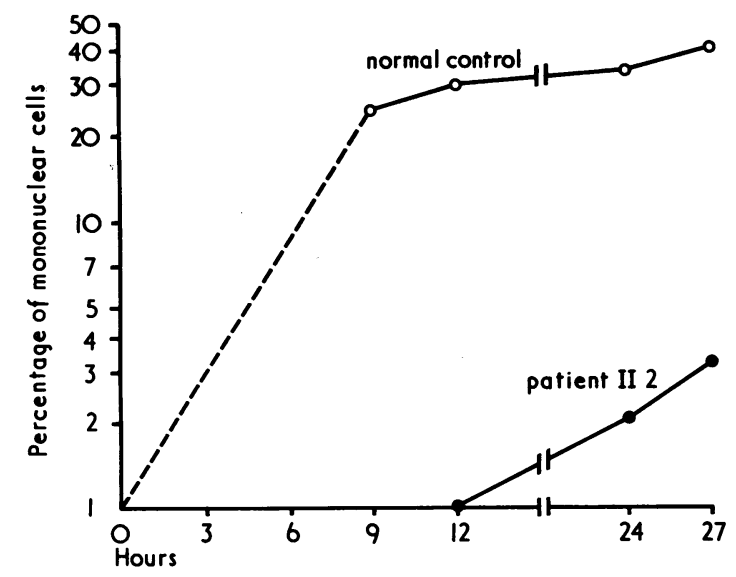

FIG. 4-Proportions of mononuclear cells in inflammatory exudate in propositus (II 2) and a normal control.

Lymphocyte Function.-Immunological studies on this family will be reported in detail elsewhere (Valdimarsson, 1972). The lymphocytes of the propositus responded normally in vitro to phytohaemagglutinin and foreign lymphocytes but failed to transform after activation with candida antigens and purified protein derivative. There was no delayed skin hypersensitivity to these antigens and sensitization with dinitrochlorobenzene also failed. These findings are consistent with the lack of circulating monocytes shown in the propositus.

\section{SERUM IMMUNOGLOBULINS}

These were estimated in nine members of the family. They were within the normal range in subjects II 2, II 4, III 1 , III 5 , and III 7. Low concentrations of IgA were found in the mother (I 2) and two of her sisters (I 3 and I 4)-90, 100, and $76 \mathrm{mg} / 100 \mathrm{ml}$ respectively (normal range for their ages $125-$
$425 \mathrm{mg} / 100 \mathrm{ml})$. Six other siblings of the mother were not investigated and are thus excluded from Fig. 1 (broken line). The 7-year-old daughter of the propositus (III 3) was found to have IgA levels of $45 \mathrm{mg} / 100 \mathrm{ml}$ (normal for her age $73-250 \mathrm{mg}$ ) $100 \mathrm{ml}$ ). Family members with low concentrations of $\mathrm{IgA}$ are shown in Fig. 1.

\section{CYTOGENETIC STUDIES}

These were performed in the propositus and in six apparently healthy family members, involving parental, filial, and sib generations (Fig. 1). Chromosome preparations were made by direct processing of bone marrow without phytohaemagglutinin (Tiio and Whang, 1962) and from peripheral blood lymphocytes after 72 hours of incubation with phytohaemagglutinin (Moorhead et al., 1960). The results are shown in the Table. Normal

Cytogenetic Studies

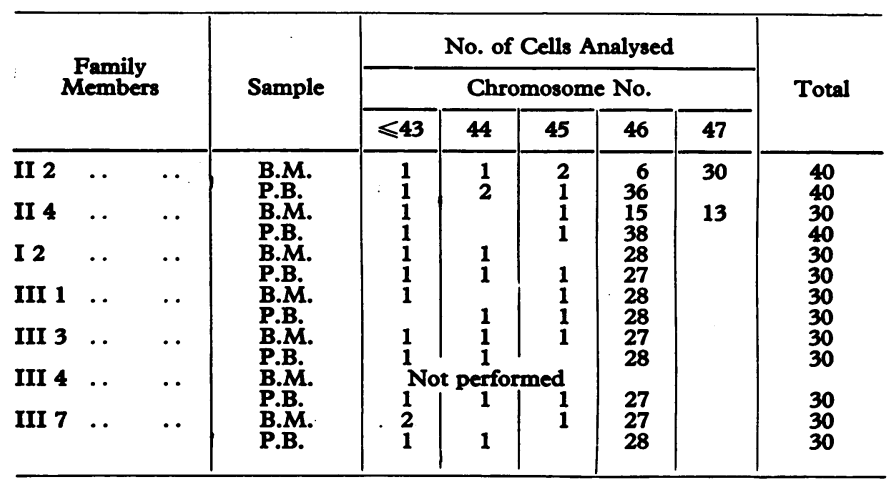

B.M. = Bone marrow (direct preparation). P.B. = Peripheral blood (72 hours' B.M. = Bone marrow (direct prepare
culture with phytohaemagglutinin).

karotypes were observed in the bone marrow and peripheral blood preparations from five family members of generations I and III. On the other hand, the propositus and his brother (II 4) showed dichotomy of the chromosome findings in peripheral blood and bone marrow preparations. Both had an abnormal clone of cells with 47 chromosomes in the bone marrow, characterized by an extra chromosome in group C (Figs. 5 and 6), while the chromosomal findings in their blood lymphocytes were normal. In the propositus $75 \%$ of the cells in the bone marrow constituted an abnormal clone, while in his brother (II 4) $43 \%$ of the cells were abnormal. In the propositus only $15 \%$ of the cells in the bone marrow showed a normal diploid pattern compared with $50 \%$ in his "unaffected" brother (II 4).

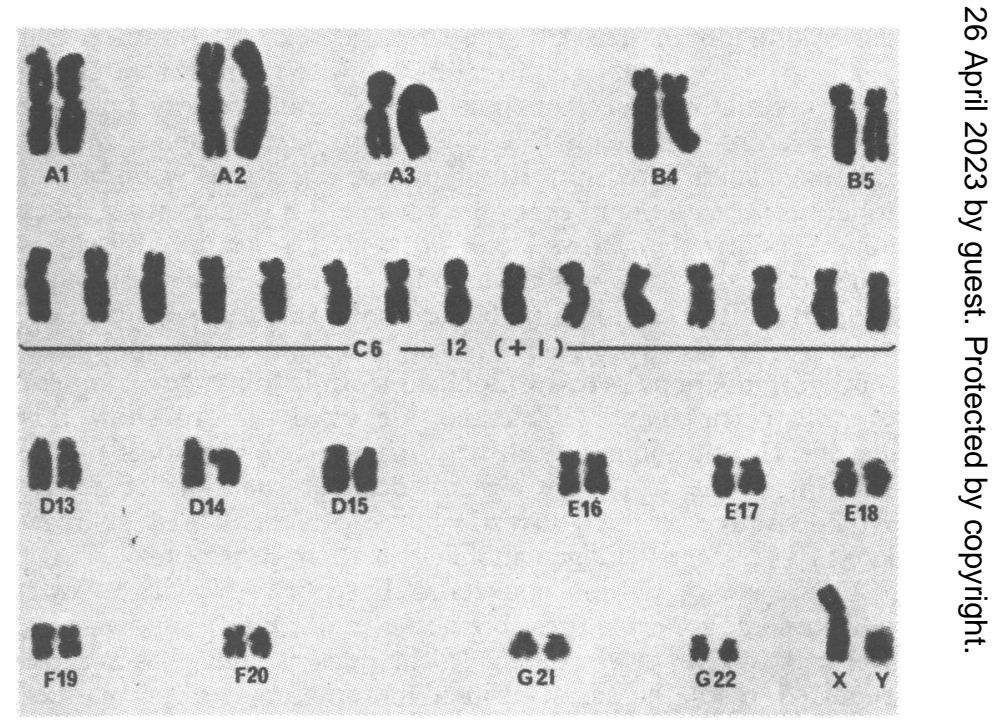

FG. 5-Karyotype of cell with 47 chromosomes from bone marrow of propositus (II 2) showing extra chromosome in C group. 


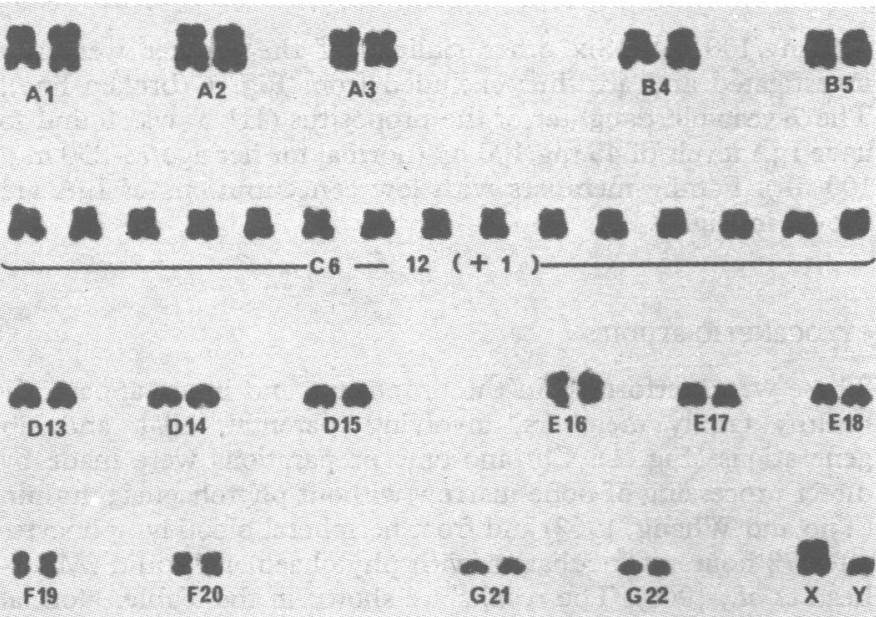

PIG. 6-Karyotype of cell with 47 chromosomes from bone marrow of case II 4 showing extra chromosome in $\mathrm{C}$ group.

In the Table cells with 43, 44, and 45 chromosomes probably represent random losses owing to technique.

\section{Discussion}

This family illustrates various related aspects of the aetiology of leukaemia in man-namely, (1) genetic factors, as suggested by the high incidence of haematological malignancy or premalignancy in one generation; (2) the development of an abnormal bone marrow clone, as shown by the chromosome abnormalities and the acquired Pelger anomaly; (3) immunological factors implied by the history of infections in the affected generation and by the presence of low IgA concentrations in various other members of the family; and (4) susceptibility to oncogenic virus, as suggested by the finding of generalized verrucosis in the two sibs with an abnormal bone marrow clone.

Genetic factors seem to play a part in at least some cases of leukaemia, as first suggested by Videbaek (1947) and reviewed by others (Zuelzer and Cox, 1969; Gunz, 1970). Genetic susceptibility has been shown in experimental animals, in studies of identical twins, and in groups with a high incidence of leukaemia, Fanconi's anaemia, and Down's syndrome (Zuelzer and Cox, 1969; Gunz, 1970; Galton and Spiers, 1971, Sutnick et al., 1971; Swift, 1971). Family studies have not shown, however, any definite pattern of inheritance (Zuelzer and Cox, 1969), although a dominant inheritance has been suggested in some families with several affected sibs. The predisposition to leukaemia in the present family probably resulted from the action of a mutant gene of large effect (Carter, 1969) rather than from constitutional abnormalities, since no chromosomal abnormalities in the lymphocytes were found. Possibly a mutant gene present in the father (I 1), expressed by hypoplastic anaemia associated with skin ulcers, was transmitted by dominant inheritance to all members of the sibship. The fact that a marker of an abnormal marrow clone-that is, the acquired PelgerHuët anomaly - was present in all the members of generation II supports this. The inherited factor may be a very specific defect resulting in non-disjunction affecting the group $\mathrm{C}$ chromosomes, rendering the bone marrow more susceptible to the development of preleukaemia and leukaemia. We were able to show this specific chromosome abnormality in only two members of the sibship, as the rest were already dead at the time of study. Other family members investigated had normal bone marrow karyotypes and no Pelger anomaly in their neutrophils.

Few cases of familial leukaemia have been associated with chromosome abnormalities (Fitzgerald et al., 1966; Snyder et al., 1970; Bottomley et al., 1971). In the present family, as in most reported cases, no constitutional chromosomal abnormalities were found. We have, however, shown the development of an abnormal bone marrow clone with 47 chromosomes co-existing with a normal one in two members of the sibship (II 2 and II 4) during the preleukaemic phase. The propositus (II 2) had already developed haematological changes compatible with preleukaemia, while his brother (II 4) had moderate pancytopenia, and the Pelger-Huët anomaly was present in his neutrophils. The anomaly in this family corresponded to the acquired form, which is not uncommon in the acute and chronic myeloid leukaemias (Sandoz, 1952; Shanbrom et al., 1960; Hayhoe et al., 1964; Wintrobe, 1968) and in preleukaemic conditions, including some refractory anaemias and Fanconi's anaemia (Blair et al., 1966; Wintrobe, 1968; Catovsky et al., 1971). Another type of granulocyte abnormality, Döhle bodies, was associated with familial acute myeloid leukaemia reported on by Goudsmit $e t$ al., (1971), and, interestingly, Döhle bodies were reported in blood films from the father (I 1) of the present sibship, although in his case they could have been due to infection.

As with the acquired Pelger anomaly, aneuploidy of the $\mathrm{C}$ group of chromosomes has often been associated with acute leukaemia, especially acute myeloid leukaemia (Sandberg et al., 1964a; Jensen, 1971), and with preleukaemic myeloproliferative conditions including myelofibrosis (Sandberg et al., 1964b; Leeksma et al., 1965; Rowley et al., 1966; Jensen, 1968; Humbert et al., 1971; Nowell, 1971). Abnormal bone marrow clones with 47 chromosomes have been reported (Sandberg et al., 1964a; Sandberg et al., 1964b; Leeksma et at., 1965; Rowley et al., 1966; Jensen, 1968; Jensen, 1971), and it was suggested that genes of the $C$ group of chromosomes may be responsible for the homoeostatic control of haemopoisis (Rowley et al., 1966). Preleukaemic conditions with a marrow chromosome abnormality carry a greater risk of subsequently developing overt leukaemia (Nowell, 1971) but, surprisingly, if this does not occur within a few months of diagnosis the subsequent risk is no greater than in similar patients without detectable chromosomal abnormality (Nowell, 1971). This could have been the case in the propositus; however, we should point out that some slow haematological progression had occurred since 1959; the left shift in granulopoiesis and the extent of the Pelger anomaly were greater. The relation between the chromosome abnormality and the Pelger anomaly on the one hand and the transformation to leukaemia on the other is not clear, but they are well known to precede leukaemia (Jensen, 1968; Catovsky et al., 1971; Nowell, 1971) and may perhaps be accepted as indicators of an underlying defect which increases the susceptibility of the cell to malignant transformation-for example, by an oncogenic virus.

An unusual haematological feature of the propositus was monocytopenia, confirmed by the near absence of the mononuclear component in his inflammatory exudate. Monocytosis is known to be associated with preleukaemia (Blair et al., 1966; Catovsky et al., 1971) but we have not found reports of monocytopenia as a feature of haematological malignancy (Wintrobe, 1968). Monocytopenia may explain some of the immunological deficiencies present in the propositus, shown in vitro by a poor response of his lymphocytes to specific antigens and in vivo by his acute and chronic infections. This finding provided a unique opportunity to study the interaction between monocytes and lymphocytes (Valdimarsson, 1972).

Another feature of this family was the development of common warts in three members, including the rare disseminated form (generalized verrucosis) (Rook et al., 1969) in the two sibs with an abnormal bone marrow clone. This lesion is known to be produced by human papilloma virus (Rook et al., 1969; Allen and Cole, 1972; Butel, 1972), a small DNA virus member of the papova group, which is the only virus currently known to produce tumours in man (Butel, 1972). As this oncogenic virus does not grow in culture it is difficult to demonstrate increased susceptibility to viral transformation in vitro (Allen and Cole, 1972). Interestingly, another member of the papova group, SV40, has been shown to increase the rate of transformation in vitro of skin fibroblasts from patients at high risk of developing leukaemia such as those with Fanconi's anaemia and Down's syndrome (Todaro and Martin, 1967; Dosik et al., 1970) and in 
members of a family with a high incidence of acute myeloid leukaemia (Snyder et al., 1970). Perhaps there is a similar increased susceptibility to malignant transformation by viruses in this family also. Other factors might have had a contributory effect-for example, the propositus appeared to be deficient in monocytes and macrophages, which are important in the defence against viral pathogens (Silverstein, 1970).

The possible role of immunodeficiency in the pathogenesis of leukaemia has already been mentioned (Galton and Spiers, 1971), and in this context it is interesting that low concentrations of IgA were present in several members of the family (Fig. 1) as in another, rather similar familial acute myeloid leukaemia (Snyder et al., 1970). In the present family it appears that the IgA deficiency was inherited from the mother (I 2) and was not a simple dominant characteristic. That this association between inherited leukaemogenic factors and immunodeficiencies might not be fortuitous is suggested by the work of Sutton et al. (1969), who found lower concentrations of IgA in siblings of leukaemic children. Further evidence is provided by the numerous reported cases of the association of lymphoreticular malignancy and cellular and humoral immunodeficiency (Freeman et al., 1970; Galton and Spiers, 1971; Potolsky et al., 1971).

Although genetic predisposition seems the most likely explanation of our findings, the possibility of "vertical" transmission, as in the virus-induced murine leukaemias (Huebner and Todaro, 1969) and as suggested for familial leukaemia in man by Heath and Moloney (1965), must also be considered.

We thank Professor J. V. Dacie, Dr. D. A. G. Galton, and Dr. J. M. Goldman for advice and encouragement; Dr. M. B. Slavin for the immunoglobulin estimations; and Dr. C. O. Carter for his suggestions after reviewing the manuscript. J. K. is a Berry Trust scholar from the Postgraduate Institute of Medical Education and Research, Chandigarh, 12, India.

Requests for reprints should be addressed to D. C., M. R. C. Leukaemia Unit, Royal Postgraduate Medical School, London W.12.

\section{References}

Allen, D. W., and Cole, P. (1972). New England fournal of Medicine, 286, 70. Blair, T. R., Bayrd, E. D., and Pease, G. L. (1966). Journal of the American Medical Association, 198, 21.

Bottomley, R. H., Trainer, A. L., and Condit, P. T. (1971). Cancer (Philadelphia), 28, 519 .

Butel, J. S. (1972). Fournal of the National Cancer Institute, 48, 285.

Carter, C. O. (1969). An A.B.C. of Medical Genetics. London, Lancet.

Catovsky, D., Shaw, M. T., Hoff brand, A. V., and Dacie, J. V. (1971). British fournal of Haematology, 20, 385 .

Dosik, H. et al. (1970). Blood, 36, 341 .
Fitzgerald, P. H., Crossen, P. E., Adams, A. C., Sharman, C. V., and Gunz, F. W. (1966). Fournal of Medical Genetics, 3, 96

Fraumeni, J. F., jun., Vogel, C. L., and DeVita, V. T. (1969). Annals of Internal Medicine, 71, 279.

Freeman, A. I., Sinks, L. F., and Cohen, M. M. (1970). fournal of Pediatrics, 77, 996.

Galton, D. A. G., and Spiers, A. S. D. (1971). Progress in Hematology, 7, 343

Gibson, R. W., et al. (1968). New England fournal of Medicine, 279, 906. Goudsmit, R., Leeuwen, A. M. van, and James, J. (1971). British fournal of Haematology, 20, 557 . Gunz, $\mathrm{F}$. W. (1970). Proceedings of the XIII Congress of the International
Society of Hematology, Munich, p. 48.

Gunz, F. W., and Veale, A. M. O. (1969). Fournal of the National Cancer Institute, 42, 517.

Hayhoe, F. G. J. (1960). Leukaemia: Research and Clinical Practice. London, Churchill.

Hayhoe, F. G. J., Quaglino, D., and Doll, R. (1964). Cytology and Cytochemistry of Acute Leukaemias. London, H.M.S.O.

eath, C. W., jun., and Moloney, W. C. (1965). New England fournal of Medicine, 272, 882.

Huebner, R. J., and Todaro, G. J. (1969). Proceedings of the National Academy of Sciences, 64, 1087.

Humbert, J. R., Hathaway, W. E., Robinson, A., Peakman, D. C., and Githens, J. H. (1971). British fournal of Haematology, 21, 705.

Jensen, M. K. (1968). Acta Medica Scandinavica, 183, 535.

Jensen, M. K. (1971). Acta Medica Scandinavica, 190, 429.

Leeksma, C. H. W., Friden-Kill, L., Brommer, E. J. P., Neuberg, C. W., and Kerkhofs, H. (1965). Lancet, $2,1299$.

Lehrer, R. I., and Cline, M. J. (1969). fournal of Bacteriology, 98, 996.

McPhedran, P., Heath, C. W., and Lee, J. (1969). Cancer (Philadelphia), 24, 403 .

Moorhead, P. S., Nowell, P. C., Mellman, W. J., Battips, D. M., and Hungerford, D. A. (1960). Experimental Cell Research, 20, 613.

Nowell, P. C. (1971). Cancer (Philadelphia), 28, 513.

Park, B. H., Fikrig, S. M., and Smithwick, E. M. (1968). Lancet, 2, 532.

Potolsky, A. I., Heath, C. W., jun., Buckley, C. E., and Rowlands, D. T., jun. (1971). American fournal of Medicine, 50, 42.

Rebuck, J. W., and Crowley, J. R. (1955). Annals of the New York Academy of Sciences, 59, 757.

Rook, A., Wilkinson, D. S., and Ebling, F. J. G. (editors) (1969). Textbook of Dermatology, $\mathrm{p} .755$. Oxford, Blackweil Scientific.

Rowley, J. D., Blaisdell, R. K., and Jacobsen, L. O. (1966). Blood, 27, 782.

Sandberg, A. A., Ishihara, T., Kikuchi, Y., and Crosswhite, L. H. (1964a). Annals of the New York Academy of Sciences, 113, 663 .

Sandberg, A. A., Ishihara, T., and Crosswhite, L. H. (1964b). Blood, 24, 716.

Sandoz Ltd. (1952). Atlas of Haematology, p. 54. Basle, Sandoz, Ltd.

Shanbrom, E., Collins, Z., and Miller, S. (1960). American fournal of the Medical Sciences, 240,732.

Silverstein, S. (1970). Seminars in Hematology, 7, 185.

Snyder, A. L., Li, F. P., Henderson, E. S., and Todaro, G. J. (1970). Lancet, 1,586

Sutnick, A. I., London, T., Blumberg, B. S., and Gerstley, B. J. S. (1971). Fournal of the National Cancer Institute, 47, 923.

Sutton, R. N. P., Bishun, N. P., and Soothill, J. F. (1969). British fournal of Haematology, 17, 113.

Swift, M. (1971). Nature, 230, 370.

Tjio, J. H., and Whang, J. (1962). Stain Technology, 37, 17.

Todaro, G. J., and Martin, G. M. (1967). Proceedings of the Society for Experimental Biology and Medicine, 124, 1232.

Valdimarsson, H. (1972). To be published.

Videbaek, A. (1947). Heredity in Human Leukaemia and its Relation to Cancer. London, Lewis.

Wintrobe, M. M. (1968). Clinical Hematology, p. 236. Philadelphia, Lea and

Febiger.
Zuelzer, W. W., and Cox, D. E. (1969). Seminars in Hematology, 6, 228.

\section{Acute Zinc Toxicity in Haemodialysis}

\section{EILEEN D. M. GALLERY, JEANETTE BLOMFIELD, S. R. DIXON}

British Medical fournal, 1972, 4, 331-333

\section{Summary}

A country patient on home haemodialysis suffered acute nausea, vomiting, and fever during dialyses when she

Sydney Dialysis Centre and Medical Research Department, Sydney Hospital, Sydney, N.S.W. 2000

EILEEN D. M. GALLERY, M.B., B.S., Registrar, Immunology and Renal Unit

Children's Medical Research Foundation, Royal Alexandra Hospital for Children, Camperdown, N.S.W. 2050

JEANETTE BLOMFIELD, M.SC., Senior Research Officer

University of Melbourne and Royal Children's Hospital, Parkville, Victoria 3052

S. R. DIXON, M.B., M.R.A.C.P., Research Fellow and Clinical Supervisor Now Renal Physician, Medical Unit, Dunedin Hospital, Dunedin, New Zealand) used water stored in a galvanized tank. She subsequently was found to have severe anaemia with raised plasma and erythrocyte zinc concentrations. Intercurrent hospital haemodialyses and subsequent home dialyses with deionized water were symptom-free.

Experimental haemodialyses of dogs against small concentrations of zinc showed a disproportionate rise in plasma zinc and possible uptake of zinc by the liver.

\section{Introduction}

The possibility that metallic poisoning might occur in dialysed patients as a result of transfer of metals present in low concentrations in dialysis solution has been shown (Maher et al., 1964; Maher et al., 1965) but only copper poisoning has been 